\title{
КЛІПОВА ХАОТИЧНІСТЬ ЯК ЗАСІБ АБСУРДИЗАЩІї ТА МАНІПУЛЯТИВНА ТЕХНОЛОГІЯ
}

\section{Чаплак Ян Васильович}

Кандидат психологічних наук, дочент, доиент кафедри психології Чернівецьького національного університету імені Юрія Федьковича, м. Чернівизі (Україна)

\section{Зварич Ігор Михайлович}

Доктор філологічних наук, професор, професор кафедри психології, декан факультету педагогіки, психології та сочіальної роботи Чернівецького начіонального університету імені Юрія Федьковича, м. Чернівці (Украӥна)

Анотація. Стаття присвячена теоретичному аналізу наукової літератури щзодо застосування кліпової хаотичності з метою актуалізаџії абсурдності змісту інформації на теренах кіберпростору як новітньої маніпулятивної технології цілеспрямованого впливу на індивідуальну та масову свідомість. Охарактеризовано новітні інформаційно-комунікативні технології, що можуть призвести до непоправних небезпечних наслідків для нашого суспільства.

Констатується, щчо кліпова хаотичність кіберпростору як засіб абсурдизації та маніпулятивна технологія соціально-психологічного впливу в інформаційному просторі пери за все спрямована на часткове, або повне «розбалансування» гармонійного співвідношення між концептуальним і кліповим рівнями мислення.

Зроблено висновок про те, щчо еволючійний період зміни свідомості людини в самому розпалі, особистість ще не дійшла до того рівня розвитку, щзоб в результаті хаотизаціі інформаційно-комунікативних потоків (марафонів) на достатньому рівні вміти трансформувати свій когнітивно-стратегічний потенціал і встигати займатися ефективною обробкою інформації за короткий часовий проміжок. А ие, водночас, надає можливість застосовувати маніпулятивні технології впливу на індивідуальну та соціальну свідомість.

Ключові слова: кліпова хаотичність кіберпростору, логіка абсурду, абсурдизація, кліпова культура, кліпове мислення, концептуальне мислення.

Постановка проблеми. Науково- світу, який неабияк вплинув на особистість технічний прогрес сприяє утворенню нового людини та ії життєдіяльність. Він викликав 
глобальні зміни не тільки на рівні зовнішніх проявів особистості, але й заглибився на внутрішніх, кардинально змінюючи іiі картину світу. Життєдіяльність людини в період насиченого та безперервного інформаційного потоку перевантажує іï як психічно так і фізично. Цьому певною мірою сприяє стрімкий процес кліповізації сучасної загальнолюдської культури, що є одним із основних атрибутів техногенного суспільства сьогодення та своєрідним результатом нашої еволюції. Але із застосуванням маніпулятивних технологій соціальнопсихологічного впливу щодо цілеспрямованого зациклення соціуму на кліповому сприйманні може призвести до деградації суспільства, викликаючи в ньому утворення стрімких інформаційних потоків розповсюдження дезінформації та суперечливого контенту, що неабияк може вплинути на утворення викривленої картини світу та утворенню непередбачуваних катастроф.

Тобто такі новітні інформаційнокомунікативні технології можуть призвести до непоправних небезпечних наслідків для нашого суспільства. По-перше, інформаційні технології в інформаційно-комунікативному просторі не завжди аналізуються на рівень екологічності, що може призвести до неконтрольованого хаосу в соціумі, або це може призвести до повномасштабної інформаційної експансії. По-друге, такий бурхливий розвиток технологічного прогресу може посприяти виникненню штучного інтелекту, який буде домінувати над людським розумом. Якщо ж у першому випадку суспільство більш-менш намагається справитися 3 тими чи іншими загрозами в інформаційному просторі за допомогою постійного удосконалення технологій інформаційної безпеки відповідно до безперервного та стрімкого прогресу сучасних технік інформаційного впливу, то в іншому випадку ситуація знаходиться на рівні невизначеності не тільки в межах «екологічності-не екологічності», але й щодо перспективи існування соціуму в умовах домінування штучного інтелекту.

Потрібно зазначити, що в цих двох випадках застосовуються новітні технології кліпової хаотичності інформаційного простору та штучної побудови інформаційно-комунікативних потоків 3 «начинкою» абсурду, які не завжди піддаються законам раціональної логіки. Загроза інформаційній безпеці нашого суспільства полягає в тому, що переважна більшість 3 них носять маніпулятивний характер.

\section{Аналіз останніх досліджень і публіка-}

цій. Сьогодні науковий світ в інтенсивній формі дискутує щодо впливу кіберпростору на особистість людини (Д. Бойко, С. Бондаренко, Н. Грищенко, М. Кастельс, Н. Луман, М. Маклюен, Е. Морен, Н. Миронова, У. Тоффлер, В. Штанько, Н. Юдіна тощо). Вивчаються технології соціально-психологічного впливу в інформаційно-комунікативному просторі на індивідуальність і суспільство (В. Баришполець, Ю. Гундертайло, Т. Кабаченко, Д. Литвин, В. 
Маркін, В. Молодняков, В. Москаленко, Н. Еппле, М. Поліщук, Г. Почепцов, О. Сидоренко, П. Таранов, В. Циганова, Д. Шарп тощо) з метою створення інструментарію в різних сферах інформаційної безпеки (В. Баришполець, П. Горностай,В. Грачов, Л. Дорош, О. Давиборець, Б. Кормич, В. Лєпський, С. Пудіч, Н. Уханова тощо).У цьому напрямі дослідження науковці приділяють досить велику увагу висвітленню питання інформаційної експансії (І. Дзялошинський, В. Макаров, А. Манойло, О. Саприкін, Л. Чуйкова тощо). Аналізу проблеми щодо створення штучного інтелекту присвячені праці таких науковцівдослідників як М. Антипов, С. Возняк, С. Гокінг, Д. Деннет, I. Макс, Д. Сьорл, Ю. Н. Харарі тощо.

Крім цього, на сьогоднішній момент в наукових колах проявляться неабиякий ажіотаж у розгляді таких понять, як «кліпове сприймання», «кліпова свідомість», «кліпове мислення» та «кліпова культура» взагалі (Н. Азарьонок, М. Антипов, В. Богданова, Ф. Гіренок, Д. Горлач, А. Градюшко, С. Докука, В. Курбатов, М. Маклюен, С. Малахова, I. Пендікова, Т. Семеновських, С. Сімакова, Е. Тоффлер, О. Фрідман, К. Фрумкін, О. Шалагіна тощо). Більшість науковців-дослідників вважає суспільну кліповість сьогодення закономірним явищем, до якої людству потрібно адаптуватися (I. Березовська, Д. Горлач, I. Пендікова, С. Сімакова тощо).

Не залишається поза увагою вчених таке поняття як «логіка абсурду», яке розглядається в більшості наукових праць як важливий соціальний феномен сьогодення (Д. Бойко, О. Буреніна, О. Калмиков, А. Камю, І. Шамша тощо).

К. Лобанова у своїй роботі виокремлює такі групи досліджень поняття абсурду: 1) дослідження абсурду в різних галузях знання та класифікації типів абсурду (Л. Антипенко, О. Вдовиченко, Ж. Делез, М. Дюпонтьє, А. Камю, Ж. Лакан, Ф. Ніцше, Ж.-П. Сатр, Б. Смірнова, А. Шопенгауер, Е. Фромм, М. Фуко, С.Франк, М. Хайдеггер, К. Ясперс тощо); 2) статті, дисертації, монографії, документи, в яких розглядаються суперечності соціальної дійсності, проблеми, що виникають у суспільстві сьогодення, які представляють форми прояву абсурдизму (Т. Адорно, Р. Барт, М. Бахтін, П. Вайнгарт, О. Зеніна, В. Карасик, Ж. Ліповецкі тощо); 3) праці, в яких здійснюється пошук шляхів подолання абсурдизму (Ф. Василюк, М. Вебер, А. Камю, Д. Карнегі, Р. Кочюнас, Ю. Шрейдер тощо) [9].

Метою статті $\epsilon$ теоретичний аналіз наукової літератури щодо застосування кліпової хаотичності з метою актуалізації абсурдності змісту інформації на теренах кіберпростору як новітньої маніпулятивної технології цілеспрямованого впливу на індивідуальну та масову свідомість.

Виклад основного матеріалу. Починаючи 3 кінця XX століття, в межах філософії науки досить актуальними стали дослідження 
щодо формування штучного інтелекту. Подібна проблематика в науковому світі виникла через «лавинну» прогресію становлення сучасних технологій в різноманітних галузях науки. Це призвело до того, що в сучасному світі життєдіяльність нашого суспільства вже не в змозі повноцінно існувати без технічного забезпечення. Сьогодні дуже багато науковців-дослідників різних галузей науки інтенсивно працюють над дослідженням перспектив та проблем у створенні штучного інтелекту.

Як зазначає М. Антипов, на сучасному етапі праці науковців-дослідників над цією проблематикою розділилися на два напрями: на тих, хто вважає можливим створення подібного пристрою (штучного інтелекту), і тих, хто ставиться досить скептично до такої ідеї [1]. Д. Деннет порівнює роботу нашого мозку 3 роботою комп'ютера, а всі наші мисленнєві функції та здібності розуму співвідносить 3 програмним забезпеченням, яке інстальоване в головний мозок [4]. Д. Сьорл вважає, що робота сучасної комп'ютерної системи 3 інформацією досить суттєво відрізняється від мисленнєвої активності особистості, вона не може вникнути в сутність і не визначає смисл. Тобто, на думку науковця, програмному забезпеченню комп’ютерної техніки доступна лише синтаксична складова знакової інформації, але ніяк не семантична (смислова) [13]. Це вказує на те, що людина завжди буде домінувати над штучними програмами обробки інформації. Але, на нашу думку, прогресивність сучасних технологічних розробок $є$ досить непередбачуваною, що певною мірою ускладнює вибір тих чи інших поглядів на цю проблематику. Тут потрібно зупинися перш за все на визначенні рівня екологічності тих чи інших розробок щодо створення штучного інтелекту.

Так, наприклад, більшість провідних вчених та винахідників сьогодення закликають людство відмовитися від технологій у створенні зброї зі штучним інтелектом. С. Гокінг заявляв, що якщо людство не в змозі буде контролювати штучний інтелект, то програє в кінцевому результаті, так як суспільство обмежене рамками біологічної революції та не зможе конкурувати 3 машинами [17]. Ю. Н. Хараpi зосереджує увагу на тому, що коли улюдства будуть алгоритми, які здатні розуміти людей краще, ніж вони самі себе, то ці алгоритми зможуть передбачати бажання, маніпулювати людськими емоціями та навіть приймати рішення. На думку науковця, якщо суспільство не проявить обережність, то може настати епоха цифрової диктатури [14]. I. Маск допускає можливість, що штучний інтелект, який створений, наприклад, тими чи іншими авторитарними режимами, зможе стати досить небезпечним явищем для всього людства. На його думку, ця технологія може стати найбезпечнішою для людства [19]. Такої думки дотримується Ю. Н. Харарі: «Контроль інформації дозволить світовим елітам зробити ще дещо радикальніше, ніж цифрова диктатура. «Зламуючи» організми, еліти отримають мож- 
ливість перебудувати майбутнє життя. I це буде найбільша революція в історії не просто людства, а всього живого на Землі. Протягом 4 млрд. років правила існування життя на планеті не змінювалися, все живе підкорялося законам природного відбору та органічній біохімії. Але зараз наука замінює еволюцію 3 допомогою природного відбору еволюцією 3 допомогою розумного задуму. Задуму не божого, а людського. Якщо не врегулювати це питання, невелика група людей, еліта, отримає до неї доступ і буде визначати майбутнє життя на Землі» [14]. Один із провідних програмістів сьогодення, співзасновник відомої компанії Apple C. Возняк зосереджує свою увагу на тому, що розвиток штучного інтелекту потенційно небезпечний для людини: «Я погоджуюся з С. Гокінгом і I. Маском, які попереджали, що майбутнє суспільства може виявитися досить сумбурним. Рано чи пізно «розумні» пристрої, які задумані для полегшення нашої життєдіяльності, зможуть розуміти, що вони - кращі за людину. Хто буде тоді керувати компаніями - повільна людина чи машина?»- говорив С. Возняк [17].

Хоча, М. Цукерберг назвав «безвідповідальною» позицію вчених стосовно загроз, що несе людству розвиток штучного інтелекту. «Штучний інтелект зробить в майбутньому наше життя кращим, а передбачати кінець світу дуже безвідповідально», - заявляє основоположник соціальної сітки Facebook [19]. С. Возняк вважає, що якщо ма- шини стануть незалежними мислителями, то будуть вічними партнерами людей, які стоять над усіма іншими видами. На думку науковця, навіть якщо машини зможуть думати, так само як і люди, вони все одно ніяк не зможуть дослухатись до власної інтуїції чи висловлювати те, що вони робитимуть згодом і що в них у результаті може 3 цього утворитися [17]. Б. Гейтс заявляє, що саме штучний інтелект має найбільший потенціал кардинально змінити життедіяльність людини: зробити іï більш продуктивнішою, ефективнішою та легшою в цілому [18].

Однак, на основі свого дослідження М. Антипов зосереджує увагу на тому, що «замість здійснення мрії про побудову штучного розуму, що означало би появу машин, які би були на рівні з людиною, людина сама опускається на рівень машини в результаті трансформації мислення під впливом екранної культури та мас-медіа». Тобто, на думку науковця, під безпосереднім впливом кліпової культури у свідомості особистості формуються утворення, які роблять іiі подібною комп'ютерній системі - притаманне людині аналітичне мислення, спрямоване на розуміння смислів, витісняється кліповим мисленням, яке здатне здійснювати операції з досить великим об'ємом інформації, але без відповідного рівня ії розуміння та без заглиблення в іiі суть [1]. В. Курбатов також вказує на те, що кліпова культура сьогодення може бути досить небезпечною для нашого суспільства, 
зосереджуючи увагу на тому, що критичне мислення не дає змоги людині бути цілісною, глибокою та особистісною [8]. Хоча, в переважній більшості, науковці-дослідники вказують на те, що кліпове мислення - це результат інформаційної реальності, яку потрібно прийняти та адаптуватися до неї.

I. Пендікова зазначає з цього приводу, що дуже недалекоглядно розглядати специфіку та сутнісні характеристики кліпового мислення тільки в ракурсі того, що воно може призводити до певних труднощів 3 концентрацією уваги, розсіювання, відсутності аналітичного складника тощо. Дослідниця зосереджує увагу на тому, процес кліповості в отриманні інформації, безперечно, вимагає кардинально нового характеру іiї обробки та утворює кардинально новий тип мислення - концептуальний, в якому функції аналізу та синтезу нікуди не зникають, а переходять на новітній, вищий щабель узагальнення інформації та виявлення відповідних смислів, а свідомість, яка розвивається у певному контексті кліпового кіберсередовища, не може не продукувати евристичних рішень тих чи інших завдань як у професійній діяльності, так і в повсякденній [11]. Тобто, кліпове мислення виступає одним із фундаментальних етапів розвитку концептуального мислення. I без відповідної наявності в людини кліпового мислення неможливе утворення концептуального осмислення буття як такого [15]. За визначенням І. Пендікової, концептуальне мислення - це такий тип мислен- ня, який вибудовується на основі нового синкретизму моральних, раціонально-логічних, художньо-естетичних парадигм мислення, що дає змогу оперувати різноманітними i, в певних випадках, неспівставними (нетотожними) 3 позицій традиційної логіки образами та поняттями, знаходячи між ними неочевидні зв'язки та припускаючи вирішення відповідної проблеми на основі творчого інноваційного підходу [11, с.55]. Узагальнюючи вищесказане дослідницею, можна зробити висновок, що кліпова культура спрямована, в першу чергу, на адаптацію до нових умов життєдіяльності особистості людини.

Проте маніпулятивні технології цілеспрямованого соціально-психологічного впливу в інформаційному просторі перш за все спрямовані на «розбалансування» оптимального співвідношення між концептуальним і кліповим рівнями мислення. У процесі цього «розбалансування» особистість не в змозі ефективно оперувати досить масштабним об'ємом інформаційних потоків, одночасно та паралельно відсіюючи непотрібні дані, та знаходити, аналізувати ту інформацію, що є більш важливою та яку можна інтегрувати у відповідний цілісний суб'єктивний образ об'єктивної дійсності. Це, в свою чергу, можна пояснити ще й тим, що процеси створення інформаційних потоків із застосуванням інформаційно-психологічних технологій у побудові «...штучно-маніпулятивної кліпової хаотичності, спрямовані не на раціональне осмислення 
всього потоку інформації, а на навіювання «потрібних» стійких смислів за допомогою інсценування аудіовізуальних ефектів тощо» [15, с. 34]. Такі варіації можуть призвести до того, що кліпове мислення як одна із складників концептуального мислення може перетворитися в домінуючий смисл комунікативної та пізнавальної активності сучасного суспільства.

3 цього приводу Г. Почепцов зазначає: «Інформація створює реальність: потрібна інформація створює потрібну реальність. Але спочатку інформація створює потрібну реальність в головах, оскільки тоді розум починає бачити в реальності те, про що йому розповідають. I чим інтенсивніший цей потік квазіінформування, то тим більше шансів він має на успіх» [12]. Це, в свою чергу, говорить про те, що інформаційні потоки тих чи інших політичних, соціальних, економічних, релігійних, духовних інституцій ведуть боротьбу за відповідний символічний капітал, право та можливість трансформувати його відносно основних цілей своїх соціальних проектів, застосовуючи новітні технології сучасного наукового світу щодо створення кліпової хаотичності на теренах кіберпростору. А сам же символічний капітал, в свою чергу, дасть можливість вільно використовувати такі технології символічної культури як: міф, ритуал і номіналізацію. В кінцевому результаті, такий символічний капітал стає могутньою технологією цілеспрямованого соціально-психологічного впливу на свідомість індивідуальності та мас [15].

Останнім часом ми можемо спостерігати за процесом як за допомогою темпу, ритму та насиченості кліпової хаотичності інформаційно-комунікативних потоків можна змінювати рівень інтенсивності впливу на соціальну свідомість. Тобто, відбувається нав'язування вже готових смислів «потрібної» інформації, які не потрібно осмислювати (в більшості випадків, людина просто не встигає їх осмислювати). Подібні варіації маніпуляцій за допомогою створення кліповізації кіберпростору можливі й із використанням технологій, які побудовані на логіці абсурду.

Проблематика абсурду сьогодні не $\epsilon$ новою в історії нашої цивілізації: ще в давні часи люди,шукаючи гармонії та прагнення до прекрасного, досить гостро відчували присутність феномену дисгармонії, розмежованості тощо. Але саме в XX столітті проблема абсурду починає займати особливе місце в суспільній свідомості. В цей час на базі соціальних потрясінь першої та другої світових воєн виникає екзистенційна філософія абсурду. Загроза світової атомної війни сприймається як абсурд в розвитку людства, так як несе в собі загрозу знищення всього живого на Землі [9].

На сучасному етапі становлення людства ми зіштовхнулися 3 тим, що абсурд фактично оточив нас. Сьогодні абсурд як і кліпова культура стає соціальним феноменом. У кожній сфері людського буття виникають абсурдні ситуації, і їх стає все більше та більше. 
Людство шукає воду на Марсі, але не береже запаси прісної води на Землі, $з$ телеекранів говорять про модернізації та нанотехнологіях, але закриваються вузи [2]. І. Шамша припускає, що саме абсурд постає тим іншим боком буття, якого воно потребує для свого існування. На думку науковця, «... абсурд, який нібито заперечує буття, як виявляється, спроможний його стверджувати в сучасному світі навіть більше, ніж класична онтологія» $[16$, с. 70$]$.

Як зазначає Д. Бойко, «... абсурд володіє своєю логікою, яка є суперечливою, божевільною, ірраціональною, в більшості випадків вона виникає раптово та неочікувано. Але завжди (рано чи пізно), коли людство зіштовхується 3 абсурдом, воно осягає (опановує) його, розуміє, що все відбувається саме так, хоча це відбувається зовсім раптово. Логіка абсурду не протистоїть звичайній, розумній логіці. Вона відтісняє те, що здається вірним i правильним, для того щоб ця ілюзія була збереженою аж до того часу, поки абсурдна логіка не продемонструє іiї неспроможність. Логіка абсурду полягає в тому, щоб спростувати логіку розуму» [2, с.15]. Хоча, на думку О. Калмикова, «...словосполучення «логіка абсурду» - оксюморон, безглуздість начебто суха вода, оскільки в логіці за визначенням не може бути абсурду, а в абсурді логіки. Тим більше в застосуванні до політики, яка нібито повинна діяти в полі раціональності, переслідуючи чиїсь досить виразні (чіткі) інтереси.
Але і в самій логіці досить багато абсурдних лакун, якими вона успішно оперує. Сформульовані ще в давнину парадокси фактично $\epsilon$ абсурдними твердженнями» [5].

Не все у сучасних досягненнях $€$ абсурдним. Дійсно, науково-технічна революція несе в собі велику, вже не приховану, а повністю очевидну небезпеку. Але розглядаючи проблеми, які виникли, не можна забувати, що завдячуючи прогресу життя змінилося до невпізнаваності. Люди можуть спілкуватися, навчатися та подорожувати за допомогою Інтернету. Немає проблеми зателефонувати друзям в Америку чи Австралію. Інвалід на колясці вчиться будь-якій справі, не виходячи 3 дому. Використовуючи сучасні технології комп'ютера та Інтернету, можна пірнути на дно Червоного моря чи поспостерігати за життям леопардів у вольєрі бразильського зоопарку. Основне завдання полягає в тому, щоб наука не знищила планету та людину, а слугувала створенню цивілізації, яка була б тісно пов'язана 3 природою та жила в злагоді з планетою [2].

Якщо б не було абсурду, то людська думка була б набагато біднішою. Саме абсурдність ситуації спонукає думати глибше та серйозніше. Через усвідомлення суперечностей людського буття народжується нова філософія [2, с. 15], яка, в свою чергу, в певній мірі видозмінює картину світу. Якщо ж проаналізувати ідеї геніїв, то, в більшості випадків спочатку свого існування вони вважалися абсурдними. Так, наприклад, більшість винаходів найзагад- 
ковішого вченого за всю історію людства Н. Тесли, в якого 800 винаходів у сфері електро та радіотехніки, вважалися абсурдними в науковому світі того часу. Хоча й певна частина 3 них все ще здаються нам фантастикою. На нашу думку, поширення абсурдизму є природною ланцюговою реакцією як наслідок сучасних технологічних революцій в різних галузях науки. На основі доведених наукових припущень і гіпотез виникає безліч нових, які ще не доведені та можуть здаватися, в певній дещо абсурдними.

Але логіка абсурду в політиці застосовується, в більшості випадків, як цілеспрямована маніпулятивна технологія, або як один із методів соціально-психологічного впливу тієї чи іншої технології (наприклад, відволікання уваги населення держави від тих чи інших подій за допомогою явних абсурдних соціальних проектів). Хоча і в політиці логіка абсурду має право на існування - в ній так само виникає безліч нових ідей, які ще не визнані суспільством. Однак такі новітні генеративні ідеї з відповідним «присмаком абсурдності» в процесі своєї реалізації переплітаються із ідеями, які заздалегідь і цілеспрямовано сформовані за штучно хибним сценарієм. Автори такої ідеї знають, що вона ніколи не зможе реалізуватися тому, що вона планувалася як хибна та деструктивна із певною маніпулятивною метою. Такі соціальні проекти із самого початку мають прихований від суспільства маніпулятивний характер.
Так, О. Калмиков указує на те, що логіка абсурду в політиці - це насправді є конкретні приклади абсурду в тій чи іншій політичній дії чи рішенні, тобто, виникає нерозуміння, здивування у громадян, які не вбачають жодного раціонального сенсу в тій чи іншій реформі, законі чи ініціативі. I справа не в тому, що політичні рішення сприймаються як помилкові, неправильні або некомпетентні, таке теж не рідкість, а саме в їх безглуздості та відсутності конкретних і зрозумілих відповідей на питання «Навіщо?», чітко побудованої мети тощо. На думку дослідника-науковця непорозуміння частково слугує руйнівною силою комунікації суспільства та влади, але, крім цього, створює смисловий вакуум, що призводить до побудови найрізноманітніших пояснювальних схем, що поширюються в основному в формі різноманітних чуток (від підозри в некомпетентності керівництва та жадібності еліт до складних конспіративних моделей) [5]. Зі сказаного вище можна зробити висновок, що штучно створена абсурдизація в інформаційному потоці як маніпулятивна технологія автоматично може надати можливість у реалізації інших маніпулятивних схем. О. Буреніна з цього приводу вказує на те, що абсурд з'являється там і в тому місці, де виникає криза буття, а слідом за ним відбувається криза думки та мови [3]. Ми можемо спостерігати абсурдизм та абсурдизацію переважної більшості інформаційно-комунікативних потоків на теренах країн з нестабільною ситуаці- 
єю в різноманітних соціальних сферах, фіксуючи кризу думки та мови.

Проаналізувавши інформаційно-комунікативний простір сьогодення, можна зробити висновок, що сучасні політичні та олігархічні еліти (особливо в нестабільних державах) стараються зосередити в своїх руках інноваційні технології щодо цілеспрямованого соціально-психологічного впливу на суспільство за допомогою кліпової хаотизації та штучного створення абсурдизму в тих чи інших інформаційно-комунікативних потоках. Але, як слушно зазначає Ю. Н. Харарі: «Багато політиків як музиканти: вони грають на людських емоціях і біохімічній системі. Політик проголошує промову, і вся країна охоплена страхом. Політик публікує «твіт», і - вибух гніву. Не думаю, що потрібно давати цим «музикам» найдосконаліші інструменти і тим паче довіряти життя у Всесвіті. Окрім всього іншого, у них навіть немає свого бачення майбутнього. Замість цього вони «годують» публіку ностальгічними фантазіями про минуле. Перш за все, там було не так вже й «класно» - побувати там вам би не захотілося. До того ж минуле не вернеться. Тому ностальгічні фантазії - не є вирішенням дискомфорту соціального бутТя» [14].

Так, наприклад, рівень довіри громадян однієї держави до абсурдних дій своєї політичної еліти дивує когнітивних психологів, соціологів і політологів: переважна більшість людей підтримує керівництво в анексії тери- торій інших держав, в готовності активізувати військову агресію проти сусідньої країни тощо. При цьому, ті громадяни, які виступають проти таких дій, потрапляють в категорію «внутрішніх ворогів». Не можна сказати, що подібні речі відбуваються в одну мить, подібний процес вимагає рутинної та злагодженої роботи різноманітних інституцій, кожна 3 яких має виступати певною часткою у створенні відповідної картини світу для своїх громадян.

У подібних соціальних проектах технології маніпулятивного впливу можуть бути спрямовані на ототожнення інтересів керівництва із інтересами самої держави чи домінуючої політичної сили в країні, наприклад, за принципом відомої фрази В. Маяковського «Партія та Ленін - брати-близнюки». Тут застосовуються старі та ефективні технології пропаганди часів «совдепу», фашистської Hiмеччини тощо.

Побудова штучних абсурдних конструкцій в політичних, економічних та соціальних інституціях може взагалі відбуватися, наприклад, за схематикою прояву абсурдизму в тій чи іншій релігійній течії, що мають свої характерні особливості тому, що релігійна віра в своїй основі $є$ досить ірраціональною. Тобто вона не завжди вкладається в ті чи інші межі логічних зв'язків та може не піддаватися принципам наукового пізнання. Так, наприклад, Пресвята Трійця - Отець, Син і Святий Дух. А потім «Вірую в Сдиного Бога Нашо- 
го...». Подібних прикладів в різних релігійних течіях можна знайти багато.

Але, як зазначає Д. Бойко, «не дивлячись на всі розмежування, алогічності та парадокси, без релігії немислима й сама людина. Тому та саме для цього вона й існує, що неможливо пізнати все та вся, що завжди буде та частина реальності, яка заставить завмерти атеїста та безбожника» [2, с.17]. Подібні релігійні аспекти абсурду ми можемо віднести в категорію позитивних, які, в більшості випадків, екологічно впливали та впливають на становлення людства та є адаптованими часом щодо їх усвідомлення. Позитивні аспекти абсурду можна виокремити не тільки в релігії, але й в науці, історії, культурі тощо. Так, на думку Д. Бойко, перш ніж здійснити прорив у тій чи іншій сфері знання, людський розум висуває гіпотезу, яка зовсім не співвідноситься 3 тим, що вже $\epsilon$ в арсеналі науки. Однак саме це призводить до нового відкриття [2, c. 16].

Але коли, наприклад, аспекти релігійності переносяться в управлінські, політичні та економічні інституції сьогодення, вказуючи на те, що «Ленін і партія - єдині», то такий соціальний проект автоматично стає маніпулятивною технологією цілеспрямованого соціально-психологічного впливу 3 метою створення одного 3 різновидів авторитарного чи навіть тоталітарного режиму.

Хоча $\epsilon$ і менш елементарні соціальні маніпулятивно-деструктивні проекти 3 нав'я- зування соціуму вигідних смислів на основі абсурдних логічних зв'язків, які, в кінцевому результаті, можна застосувати в більш глобальному та складнішому. Подібні варіації абсурдних ситуацій наявні у всіх країнах світу, але в десятки (а то й і в сотні) разів їх більше в нестабільних державах, що надає можливість здійснювати повномасштабні маніпуляції зі свідомістю своїх громадян.

Коли кіберпростір перенасичений подібним абсурдизмом, що переходить в активну стадію абсурдизації (стрімке поширення потоків абсурдизму в тій чи іншій країні), то виникають такі собі «абсурдистани» (слово «абсурдистан» означає іронічну назву країни, в якій абсурдні речі стали нормою, особливо в політиці та керівництві цієї держави). Так, наприклад, складається враження, що Північна Корея - це певний дослідницький майданчик зі створеною системою «абсурдистану», на території якого інтенсивно проводяться експерименти, вдосконалюються технології маніпуляцій свідомістю індивідуальності та мас з метою побудови ще більш масштабнішого та впливовішого абсурдиського соціального середовища.

Деякі із держав, які наближені за своїм устроєм до «абсурдистану», прагнуть стати супердержавою на зразок «Океанії» із фантастичного роману Дж. Оруелла «1984», яка веде боротьбу за глобалізаційний простір з двома іншими супердержавами. У цих країнах під лозунгами: «Мир», «Свобода», «Знання» по- 
чинає вбачатися абсурдна суть: «Війна - це Мир!», «Свобода - це Рабство!», «Незнання Сила!» [10]. Крім цього, провладні еліти в таких країнах дуже дієво маніпулюють історичними даними, як і за часів існування різних імперіалістичних держав. «І якщо всі сприймають брехню, нав'язану партією, якщо у всіх документах одна і та ж пісня, тоді ця брехня поселяється в історії і стає правдою. Хто управляє минулим, - говорить партійне гасло, - той управляє майбутнім; хто управляє сьогоденням, той управляє минулим» - описує Дж. Оруелл. Історичні міфи в «абсудистанах» створюються за схемою: «І десь, незрозуміло де, анонімно, існував керуючий мозок, який зображав політичну лінію, відповідно до якої одну частину минулого потрібно було зберегти, іншу фальсифікувати, а третю знищити без залишку» [10] . Такий механізм створення міфів дуже сприятливо впливає на зміцнення імперіалістичного націоналізму та тоталітарного режиму тощо. Всі ці технології повномасштабної маніпуляції свідомістю індивідуальності та мас, в кінцевому результаті, і можуть призвести до повної інформаційної експансії чи цифрової диктатури взагалі.

Крім цього, як зазначає О. Калмиков, скориставшись логікою абсурду, можна пояснити абсурдні дії як певну спробу штучного формування організованого хаосу, та навіть керованого хаосу. Виправданий смисл у цьому $\epsilon-$ «...соціально-політичні деструктивні дії призводять до руйнації різноманітних зв'я- зків і вивільнення великої кількості соціальної енергії, як при горінні. Невелику частину цієї енергії можна спробувати утилізувати, створюючи нові структури, нові соціальні ліфти тощо» [5].

\section{Висновки та перспективи подальших}

розвідок. На нашу думку, такі соціальні проекти є небезпечними для індивіда та суспільства в цілому. Створення хаосу за допомогою абсурдизму свідчить, що зростання кліпової культури в інформаційному просторі може призвести до неконтрольованості інформаційно-комунікативних потоків (абсурдність переросте в процес абсурдизації, кліпова хаотичність - в кліпову хаотизацію). Це пояснюється тим, що інформаційні потоки на сучасному етапі вже можуть працювати з різною інтенсивністю подачі інформації і в конкурентних умовах «потрібну» інтенсивність досить важко утримувати (від інтенсивності та насиченості інформаційного потоку може змінюватися вплив на соціум), тим паче немає гарантії, що той чи інший потік не піддасться інформаційній атаці. Тільки це вже вказує на те, що кліпову хаотичність на теренах інформаційного простору на сьогоднішній момент досить важко контролювати. I фактично стає неможливим контроль штучно створеної хаотичності в інформаційному потоці, наприклад, на таких двох паралелях як кліповість та пояснення абсурдних дій створенням контрольованого чи організаційного хаосу. В кінцевому результаті, це вже буде не кліпова хаотичність, а клі- 
пова хаотизація (постійне посилення та зростання хаосу), яку фактично вже взагалі неможливо буде контролювати та стримувати на сучасному етапі становлення технологічного прогресу. Відповідні існуючі інституції інформаційної безпеки не в змозі будуть зупинити масштабну хаотизацію, тому нагальною потребою є створення алгоритмів щодо вчасного передбачення таких катастрофічних потоків на стадії їхнього становлення.

Технологічний прогрес призвів до зміни інформаційно-комунікативних засобів і до утворення новітніх різновидів розумової діяльності людини. Справа в тому, що еволюційний період зміни свідомості людини в самому розпалі, особистість ще не дійшла до того рівня розвитку, щоб в результаті хаотизації інформаційно-комунікативних потоків (марафонів) на достатньому рівні вміти трансформувати свій когнітивно-стратегічний потенціал і встигати займатися ефективною обробкою інформації за короткий часовий проміжок. А це, водночас, надає можливість застосовувати маніпулятивні технології впливу на індивідуальну та соціальну свідомість. Так, наприклад, в більшості випадків, у процесі створення сучасних деструктивно-маніпулятивних соціальних проектів в політиці застосовується механічна еклектика щодо комбінування різноманітних підходів розуміння абсурду (наприклад, метафізичного, естетичного, філософського, театрального тощо). Це теж призводить до перевантаження суспільства у сприйнятті та обробці інформаційних потоків, що може бути причиною утворення неочікуваного та стрімкого процесу масштабної хаотизації, яка є небезпечною для життєдіяльності суспільства в цілому. У своїх перспективах подальших розвідок ми плануємо продовжити дослідження кліпової хаотичності кіберпростору як маніпулятивної технології та засобу абсурдизації інформаційних потоків.

\section{Перелік використаних джерел:}

1. Антипов M. А. Клиповое мышление как атрибут техногенного общества [Электронный ресурс] / М.А. Антипов. - Режим доступа: http:/www.penzgtu.ru/ fileadmin/filemounts/filosof/staff/publish/antipov/ Antipov_10.pdf.

2. Бойко Д. В. Логика абсурда [Электронный ресурс] / Д. В. Бойко // Психология и психотехника. - № 1 (64). 2014. - С. 12-21. - Режим доступа: DOI: 10.7256/20708955.2014.1.10514.

3. Буренина О. Что такое абсурд, или по следам Мартина Эсслина [Электронный ресурс] / О. Буренина. - Режим доступа: http://www.ec-dejavu.net/a/Absurd. html.

4. Деннет Д. Виды психики: на пути к пониманию сознания [Текст] / Д.Деннет. - М.: Идея Пресс, 2004. $184 \mathrm{c}$.

5. Калмыков A. А. Логика абсурда в современной политике [Текст] / А.А.Калмыков // Вестник РГГУ. -№1 (123). - М., 2014. - C.37-46.

6. Камю А. Сочинения : в 5-ти т. [Текст] / А. Камю. [пер. с франц.]. - Х. : Фолио, 1997. - Т. 2. - 1997. - 527 c.

7. Косилова E. О национальных традициях в абсурде [Электронный ресурс] / Е. Косилова. - Режим доступа: http://fege.narod.ru/scriptorium/natio.htm.

8. Курбатов В. И. Символическое виртуальное сетевое мышление: новая эпоха, или епоха новостей [Текст] / 
В.И. Курбатов // Гуманитарий Юга России, 2013. - № 1. - C.64-74.

9. Лобанова Е. И. Абсурдизм как общественное явление современности: социально-философский анализ : автореф. дисс. на соискание уч. степени канд. филос. наук : спец. 09.00.11 «Социальная философия» [Электронный ресурс] / Е.И.Лобанова. - М. 2013. - 23 с. - Режим доступа: http://cheloveknauka.com/v/376928/a?\#?page=1 .

10. Оруэлл Дж. 1984 [Электронный ресурс] / Дж. Оруэлл. - Режим доступа: http://www.litmir.net/bd/? $\mathrm{b}=576$.

11. Пендикова И. Г. Клиповое и концептуальное мышление как разные уровни процесса мышления [Текст] / И.Г. Пендикова // Омский научный вестник. Серия «Общество. История. Современность». - 2016. №1. - C.53-56.

12. Почепцุов Г. Смисли і війни: Україна і Росія в інформаційній і смисловій війнах [Текст] / Г.Почепцов. Видавничий дім «Києво-Могилянська академія», 2016. -316 c.

13. Серл Дж. Разум, мозг и программы [Электронный pecypc] / Дж. Сёрл. - Режим доступа: http:// www.philsci.univ.kiev.ua/biblio/searle.html.

14. Харари Ю. Н. Большинство людей не осознают, что происходит: речь израильского историка в Давосе [Электронный ресурс]/ Ю.Н. Харари. - Режим доступа: https://bykvu.com/bukvy/84181-bolshinstvo-lyudej-neosoznayut-chto-proiskhodit-rech-izrailskogo-istorika-vdavose.

15. Чаплак Я. В. Кліпова хаотичність як маніпулятивна технологія соціально-психологічного впливу в кіберпросторі [Електронний ресурс] / Я. В. Чаплак, Г. В. Чуйко // Психологічний часопис : збірник наукових праць / за ред. С.Д. Максименка. - № 3. - Том 13. - К.: Інститут психології імені Г.С. Костюка НАПН України, 2018. C. 21-40. - Режим доступу: https:// doi.org/10.31108/2018vol13iss3pp21-40.

16. Шамша I. В. Трагізм і протест абсурду як відповідь на вихідну суперечливість буття [Електронний ресурс] / I. В. Шамша // Актуальні проблеми філософії та соціо- логії. Серія : Філософія. - 2014. - Вип. 2. - С. 70-76. Режим доступу: http://nbuv.gov.ua/UJRN/ aprfc_2014_2_13.

17. Штучний інтелект. Побоювання Маска і Гокінга [Електронний ресурс]. - Режим доступу:https:// ua.korrespondent.net/tech/science/3870170-shtuchnyiintelekt-pobouivannia-maska-i-hokinha.

18. Clifford C. Billionaire Bill Gates on the impact of A.I.: 'Certainly' we can look forward to longer vacations / C. Clifford [Електронний ресурс]. - Режим доступу: https:// www.cnbc.com/2018/01/29/bill-gates-artificial-intelligence -could-mean-longer-vacations.html.

19. Wagstaff $K$. Elon Musk warns that AI could become an 'immortal dictator' / К. Wagstaff [Електронний ресурс]. Режим доступу: https://mashable.com/2018/04/06/elonmusk-artificial-intelligence-chris-paine-do-you-trust-thiscomputer/\#5gY1Nts8_mqp.

\section{References (Transliteration):}

1. Antipov M. A. Klipovoe myshlenie kak atribut tekhnogennogo obshchestva [Jelektronnyj resurs] / M.A. Antipov. - Rezhim dostupa: http://www.penzgtu.ru/ fileadmin/filemounts/filosof/staff/publish/antipov/

Antipov_10.pdf.

2. Bojko D. V. Logika absurda [Jelektronnyj resurs] / D. V. Bojko // Psihologiya i psihotekhnika. - № 1 (64). - 2014. S. 12-21. - Rezhim dostupa: DOI: 10.7256/20708955.2014.1.10514.

3. Burenina $O$. Chto takoe absurd, ili po sledam Martina Esslina / O. Burenina [Jelektronnyj resurs]. - Rezhim dostupa: http://www.ec-dejavu.net/a/Absurd. html.

4. Dennet $D$. Vidy psihiki: na puti k ponimaniyu soznaniya [Tekst] / D.Dennet. - M.: IdeyaPress, 2004. - 184 s.

5. Kalmykov A. A. Logika absurda v sovremennoj politike [Tekst] / A.A.Kalmykov // Vestnik RGGU. - №1 (123). M., 2014. - S.37-46.

6. Kamyu A. Sochineniya : v 5-ti t. [Tekst] / A. Kamyu. [per. s franc.]. - H. : Folio, 1997. - T. 2. - 1997. - 527 s.

7. Kosilova E. O nacional'nyh tradiciyah $\mathrm{v}$ absurde 
[Jelektronnyj resurs] / E. Kosilova. - Rezhim dostupa: http://fege.narod.ru/scriptorium/natio.htm.

8. Kurbatov V. I. Simvolicheskoe virtual'noe setevoe myshlenie: novaya epoha, ili epoha novostej [Tekst] / V.I. Kurbatov // Gumanitarij Yuga Rossii, 2013. - № 1. - S.64 $-74$.

9. Lobanova E. I. Absurdizm kak obshhestvennoe javlenie sovremennosti: social'no-filosofskij analiz : avtoref. diss. na soiskanie uch. stepeni kand. filos. nauk : spec. 09.00.11 «Social'naja filosofija» [Jelektronnyj resurs] / E.I.Lobanova. - M. 2013. - 23 s. - Rezhim dostupa: http:// cheloveknauka.com/v/376928/a?\#?page=1.10.

10. Orujell Dzh. 1984 [Jelektronnyj resurs] / Dzh. Orujell. Rezhim dostupa: http://www.litmir.net/bd/?b=576.

11. Pendikova I. G. Klipovoe i konceptual'noe myshlenie kak raznye urovni processa myshlenija [Tekst] / I.G. Pendikova // Omskij nauchnyj vestnik. - Serija «Obshhestvo. Istorija. Sovremennost'». - 2016. - № 1. S.53-56.

12. Pocheptsov H. Smysly i viiny: Ukraina i Rosiia v informatsiinii i smyslovii viinakh [Tekst] / H.Pocheptsov. Vydavnychyi dim «Kyievo-Mohylianska akademiia», 2016. $-316 \mathrm{~s}$.

13. Sèrl Dzh. Razum, mozg i programmy [Jelektronnyj resurs] / Dzh. Sjorl. - Rezhim dostupa: http:// www.philsci.univ.kiev.ua/biblio/searle.html.

14. Harari Ju. N. Bol'shinstvo ljudej ne osoznajut, chto proishodit: rech' izrail'skogo istorika v Davose [Jelektronnyj resurs]/ Ju.N. Harari. - Rezhim dostupa: https://bykvu.com/bukvy/84181-bolshinstvo-lyudej-neosoznayut-chto-proiskhodit-rech-izrailskogo-istorika-vdavose.

15. Chaplak Ya. V. Klipova khaotychnist yak manipuliatyvna tekhnolohiia sotsialno-psykholohichnoho vplyvu v kiberprostori [Elektronnyiresurs] / Ya. V. Chaplak, H. V. Chuiko // Psykholohichnyi chasopys : zbirnyk naukovykh prats / za red. S.D. Maksymenka. - № 3. - Tom 13. - K.: Instytut psykholohii imeni H.S. Kostiuka NAPN Ukrainy, 2018. - S.21-40. - Rezhym dostupu: https://doi.org/10.31108/2018vol13iss3pp21-40.
16. Shamsha I. V. Tragizm i protest absurdu jak vidpovid' na vyhidnu superechlyvist' buttja [Elektronnyj resurs] / I. V. Shamsha // Aktual'ni problemy filosofii' ta sociologii'. Serija : Filosofija. - 2014. - Vyp. 2. - S. 70-76. - Rezhym dostupu: http://nbuv.gov.ua/UJRN/aprfc_2014_2_13.

17. Shtuchnyj intelekt. Pobojuvannja Maska i Gokinga [Elektronnyj resurs]. - Rezhym dostupu: https:// ua.korrespondent.net/tech/science/3870170-shtuchnyiintelekt-pobouivannia-maska-i-hokinha.

18. Clifford C. Billionaire Bill Gates on the impact of A.I.: 'Certainly' we can look forward to longer vacations / C. Clifford [Elektronnyj resurs]. - Режим доступу: https:// www.cnbc.com/2018/01/29/bill-gates-artificial-intelligence -could-mean-longer-vacations.html.

19. Wagstaff $K$. Elon Musk warns that AI could become an 'immortal dictator' / K. Wagstaff [Elektronnyj resurs]. Режим доступу: https://mashable.com/2018/04/06/elonmusk-artificial-intelligence-chris-paine-do-you-trust-thiscomputer/\#5gY1Nts8_mqp.

\section{Chaplak Yan}

PhD (psychological sciences), associate professor of Psychology Department, Yuriy Fedkovych Chernivtsi National University, Chernivtsi (Ukraine)

\section{Zvarych Igor}

Doctor of philology, professor, professor of the department of psychology, dean of the faculty of pedagogy, psychology and social work of Yuri Fedkovich Chernivtsi National University, Chernivtsi (Ukraine)

\section{CLIP CHAOTICNESS AS A MEANS OF ABSURDIZATION AND MANIPULATIVE TECHNOLOGY}

\section{ABSTRACT}

The article is deals with the theoretical analysis of scientific literature in reference to using of clip chaoticness in order to actualize the absurdity of the content of information on the territory of cyberspace as the latest manipulative 
technology of goal-oriented influence on the individual and mass consciousness. Such concepts as clip chaoticness of cyberspace, logic of absurdity, absurdization, clip culture, clip thinking, conceptual thinking, etc. are revealed. The newest informational-communicative technologies, which can lead to fatal dangerous consequences for our society, are described.

It is stated that the clip chaoticness of cyberspace as a means of absurdization and the manipulative technology of social and psychological influence in the information space primarily focus on the partial or complete "disbalance" of the harmonious correlation between the conceptual and the clip levels of thinking. This, by turns, tells that the information flows of various political, social, economic, religious, and spiritual institutions are fighting for the corresponding symbolic capital, the right and the opportunity to transform it relative to the main goals of their social projects, using the latest technologies of the modern scientific world to create the clip chaoticness in the areas of cyberspace.

Creating chaos using absurdism testifies that the growth of clip culture in the information space can lead to uncontrollability of informational-communicative flows (absurdity grows into the process of absurdization, clip chaoticness - in clips chaotization). This is explained by the fact that information flows at the present stage already can work with different intensity of the submission of information, and the "necessary" intensity is difficult to maintain in a competitive conditions (depending on the intensity and saturation of the information flow the influence on the society may change), especially there is no guarantee that one or the other flow will not amenable to information attack. Only this already indicates that chaoticness of clip in the areas of the informational space is difficult to control for today. And in fact it becomes impossible to control artificially created chaoticness in the information flow, for example, on such two parallels as clip and explanation of absurd actions by creation of controlled or organized chaos. In final result, it will not be the clip chaoticness, but the clip chaotization (a constant increasing and growth of chaos), which in fact at all is already impossible to control and constrain at the present stage of formation of technological progress. Relevant existing institutions of information security will not be able to stop widespread chaoticness, that's why the creation of algorithms for timely prediction of such catastrophic flows at the stage of their formation is the urgent need. It is substantiated that technological progress has led to a change in the informational-communicative means and to the formation of the latest varieties of human intellectual activity.

It is concluded that the evolutionary period of change in human consciousness is in full swing, the personality has not yet reached the level of development, in order as a result of the chaoticness of informational-communicative flows (marathons) be able to transform her cognitivestrategic potential and have time to engage in ef- 
fective information processing for a short period of time at an adequate level. And this, at the same time, provides the opportunity to apply manipulative technologies of the influence on individual and social consciousness.

Key words: clip chaoticness of cyberspace, logic of absurd, reduction to absurdity, clip culture, clip thinking, conceptual thinking.

\section{Чаплак Ян Васильевич}

Кандидат психологических наук, доиент кафедры психологии Черновиикого национального университета имени Юрия Федьковича, г. Черновцьы (Украина)

\section{Зварич Игорь Михайлович}

Доктор филологических наук, профессор, профессор кафедры психологии, декан факультета педагогики, психологии и социальной работь Черновиџкого национального университета имени Юрия Федьковича, 2. Черновиьь (Украина)

\section{КЛИПОВАЯ ХАОТИЧНОСТЬ КАК СРЕДСТВО АБСУРДИЗАЦИИ И МАНИПУЛЯТИВНАЯ ТЕХНОЛОГИЯ}

Аннотация. Статья посвящена теоретическому анализу научной литературы в отношении использования клиповой хаотичности с целью актуализации абсурдности содержания информации на территории киберпространства как новой манипулятивной технологии целенаправленного воздействия на индивидуальное и массовое сознание. Раскрываются такие понятия, как клиповая хаотичность киберпространства, логика абсурда, абсурдизация, клиповая культура, клиповое мышление, концептуальное мышление и тому подобное. Охарактеризованы новые информационно -коммуникативные технологии, которые могут привести к непоправимым опасным последствиям для общества.

Констатируется, что клиповая хаотичность киберпространства как средство абсурдизации и манипулятивная технология социально-психологического воздействия в информационном пространстве, прежде всего, направлена на частичную или полную «разбалансировку» гармоничного соотношения между концептуальным и клиповым уровнями мышления. Это, в свою очередь, говорит о том, что информационные потоки тех или иных политических, социальных, экономических, религиозных, духовных институтов ведут борьбу за соответствующий символический капитал, право и возможность трансформировать его относительно основных целей своих социальных проектов, применяя новейшие технологии современного научного мира по созданию клиповой хаотичности на территории киберпространства.

Создание хаоса с помощью абсурдизма свидетельствует, что рост клиповой культуры в информационном пространстве может привести к неконтролируемости информационнокоммуникативных потоков (абсурдность перерастет в процесс абсурдизации, клиповая хаотичность - в клиповую хаотизацию). Это объясняется тем, что информационные потоки на современном этапе уже могут работать с разной интенсивностью подачи информации и в конкурентных условиях «нужную» интенсив- 
ность достаточно трудно удерживать (в зависимости от интенсивности и насыщенности информационного потока может изменяться влияние на социум), тем более нет гарантии, что тот или другой поток не поддастся информационной атаке. Только это уже указывает на то, что клиповую хаотичность на территории информационного пространства на сегодняшний момент достаточно трудно контролировать. И фактически становится невозможным контроль искусственно созданную хаотичность в информационном потоке, например, в таких двух параллелях, как клиповость и объяснения абсурдных действий созданием контролируемого или организационного хаоca. В конечном итоге, это уже будет не клиповая хаотичность, а клиповая хаотизация (постоянное усиление и рост хаоса), которую фактически уже вообще невозможно будет контролировать и сдерживать на современном этапе становления технологического прогресса. Соответствующие существующие институты информационной безопасности не в состоянии будут остановить масштабную хаотизацию, поэтому насущной необходимостью является создание алгоритмов относительно своевременного предвидения таких катастрофических потоков на стадии их становления. Обосновывается то, что технологический прогресс привел к изменению информационнокоммуникативных средств и к образованию новых видов умственной деятельности человека.
Сделан вывод о том, что эволюционный период изменения сознания человека в самом разгаре, личность еще не дошла до того уровня развития, чтобы в результате хаотизации информационно-коммуникативных потоков (марафонов) на достаточном уровне уметь трансформировать свой когнитивностратегический потенциал и успевать заниматься эффективной обработкой информации за короткий временной промежуток. А это одновременно дает возможность применять манипулятивные технологии воздействия на индивидуальное и социальное сознание.

Ключевые слова: клиповая хаотичность киберпространства, логика абсурда, абсурдизация, клиповая культура, клиповое мышление, концептуальное мышление.

Дата отримання статті: 01.04.2018 Дата рекомендації до друку: 11.04.2018 Дата оприлюднення: 19.04.2018 